\title{
Characterisation of gelatin extracted from buffalo (Bubalus bubalis) bone using papain pre-treatment
}

Muhammad Yazid Samatra, Afifah Azmi, Sharifudin Md Shaarani, Umi Hartina Mohamad Razali *

Faculty of Food Science and Nutrition, Universiti Malaysia Sabah, 88400, Kota Kinabalu, Sabah.

\section{ARTICLE HISTORY}

Received: 16 March 2020

Received in revised form: 28 October

2020

Accepted: 2 November 2020

Available Online: 4 November 2020

\section{Keywords}

Buffalo bone

Gelatin

Papain-aided extraction

Non-enzymatic extraction

\section{Abstract}

This study was carried out to extract gelatin from the bone of Buffalo (Bubalus bubalis) by incorporating enzymatic pre-treatment. Papain-aided extraction (PE) (9.1 ppm of papain at $50^{\circ} \mathrm{C}$ water) was employed in the pre-treatment step, in which non-enzymatic extraction (NE) was carried out for comparison. The gelatin obtained were next evaluated for their physicochemical properties such as moisture, protein, and ash content, colour, and UV-vis absorption. Functional properties of the gelatin which included emulsifying and foaming properties were also determined. Four-fold increments in yield (wet basis) were obtained for PE $(29.92 \%)$ as compared to NE (7.5\%). Moreover, no significance difference $(p>0.05)$ in moisture content was observed for both $\mathrm{PE}$ and NE, although the protein content of the gelatin was observed in the range between 70-90\%. The resulting gelatin from both extractions was generally yellowish in appearance and was confirmed by the colourimetry data where no significant difference $(p>0.05)$ was observed for both samples. The maximum absorption peak for both PE and NE were observed at $210 \mathrm{~nm}$, which was in the range commonly reported for gelatin. In addition, the emulsifying and foaming capacity of PE and NE had no significant difference ( $p>0.05$ ), although emulsion stability for PE was shown to be significantly higher $(p<0.05)$ compared to NE. The present study was an attempt to evaluate the potential use of local buffalo bone as raw material for gelatin production, which found that extractability could be improved with enzymatic pre-treatment in obtaining acceptable gelatin qualities.

\section{Introduction}

Gelatin has been widely used in the food industry as an additive for stabilising, gelling, and emulsifying agent (Arioui et al., 2018), in which the market value by 2023, has been estimated to reach USD 3.53 billion at a compound annual growth rate (CAGR) of $6.6 \%$ (Research and Market, 2019). As a hydrocolloid, it is regarded as one of a kind given its distinctive functional and technological characteristics. In recent years, the application of gelatin has expanded in pharmaceutical and microencapsulation fields due to its regulating release of active ingredients and medicine delivery capacity (Research and Market, 2019).

The industrial source of gelatin raw material is often derived from the hide and bone of vertebrae such as porcine and bovine. Religious and safety constraints of these sources have led researchers to search for an alternative source of gelatin, which commonly reported, are those extracted from aquatic sources (Jamilah et al., 2011; Li et al., 2018; Mi et al., 2019). However, gelatin derived from aquatic sources is generally associated with inferior quality as compared to their mammalian counterpart given the low gelling property, thermal stability and its low amino acid content (Jamilah et al., 2011).

Nevertheless, the extractability of gelatin from raw material and the quality of the resulting gelatin is significantly affected by the steps within the pre-treatment process. The pre-treatment process is important in order to induce the weakening of intermolecular and intra-molecular bonds in the bone matrix, which promotes the breakdown of complex crosslink that exists in collagen (Ma et al., 2019). The use of protease enzyme in gelatin manufacturing especially in the pre-treatment (swelling process) stage, is consequently attracting significant attention of researchers to reduce the environmental impact and also towards the ability of the enzyme to increase the yield and quality of gelatin extracted (Ma et al., 2019). Here, modified enzymatic pre-treatment is often used to substitute the acid or liming process to hydrolyse the native collagen which demonstrates shorter processing time, higher yield and generating less water (Damrongsakkul et al., 2008; Ma et al., 2019).

Nonetheless, it is interesting to explore the underutilised group of bovine, namely Buffalo, as a raw material for gelatin production. In Asia, Buffalo (Bubalus bubalis) plays a significant role in social advancement since it provides milk, meat, skins, and draft control for agricultural activities. Buffalo bone, which is usually discarded following meat processing, is a collagen-rich biomaterial that can be utilised as gelatin raw material. Indeed, Buffalo has been reported to be resistant to prion-diseases (Zhao et al., 2016), making it a safer choice compared to other bovine counterparts. Although, limited research is found reporting on the extraction of gelatin from buffalo bone. Therefore, the current study is undertaken in an attempt to evaluate the potential use of buffalo bone as gelatin raw material using enzymatic pre-treatment.

\section{Materials and Method}

The Buffalo bones were obtained from Huswani Enterprise in Kota Kinabalu, Sabah, and maintained at a temperature of -20 ${ }^{\circ} \mathrm{C}$ until for later use. Papain enzyme EC 3.4.22.2 (from Carica papaya) 30000 USP-U/mg from Merck (Darmstadt, Germany) and commercial bovine gelatin were obtained from SigmaAldrich, United States. All chemicals used in this study were of analytical grade. 


\section{Raw material preparation}

The bones were crushed into small pieces $(1 \times 1 \mathrm{~cm})$ prior to gelatin extraction.

\section{Modified enzymatic extraction}

Pre-treatment to remove any unwanted materials from the bone was carried out according to Li et al. (2009) with slight modification. The Buffalo bone (50 g) soaked in hexane (1:15 $\mathrm{w} / \mathrm{v}$ ) for $48 \mathrm{~h}$ to remove fat. The defatted bone was then desalted using $0.5 \mathrm{~mol} / \mathrm{L}$ ethylenediamine tetra-acetic acid disodium (EDTA-2Na, pH 7.4) with $(1: 15 \mathrm{w} / \mathrm{v})$ ratio for $48 \mathrm{~h}$ at room temperature to reduce the mineral content. The defatted and desalted bone was next pre-treated with enzyme for swelling of the raw material before gelatin extraction (Hosseini-Parvar et al., 2009). The bone was then mixed with papain (9.1 ppm) in glycine buffer $(1: 10 \mathrm{w} / \mathrm{v}), \mathrm{pH} 2$ at $50{ }^{\circ} \mathrm{C}$ for $12 \mathrm{~h}$, upon which time the reaction mixture was heated at $100{ }^{\circ} \mathrm{C}$ for $1 \mathrm{~min}$ to deactivate the enzyme. The $\mathrm{pH}$ of the mixture was neutralised to 7 using $1 \mathrm{M} \mathrm{NaOH}$. Next, hot water extraction was undertaken on the pre-treated swollen bone according to Hosseini-Parvar et al. (2009) with slight modification in which temperature was set at $70.3^{\circ} \mathrm{C}$ for $72 \mathrm{~h}$. The slurry was then filtered with Whatman no. 4 filter paper and stored in a blast freezer at $-80{ }^{\circ} \mathrm{C}$ before freeze-drying.

\section{Non-enzymatic extraction}

Non-enzymatic pre-treatment was carried out as described by Arioui et al. (2018). Here, $50 \mathrm{~g}$ of buffalo bone underwent defatting and the demineralising process by soaking in $2 \% \mathrm{HCl}$ for $48 \mathrm{~h}$ at room temperature before washing with distilled water, until reaching a neutral $\mathrm{pH}$. The defatted and demineralised bone was then treated with $1 \mathrm{M} \mathrm{NaOH}$ for $48 \mathrm{~h}$ at $4{ }^{\circ} \mathrm{C}$ to remove non-protein molecule. The extraction of gelatin was carried out according to Hosseini-Parvar et al. (2009) where the bone was soaked in distilled water $(1: 3 \mathrm{w} / \mathrm{v})$ at a temperature of $70.3^{\circ} \mathrm{C}$ for $72 \mathrm{~h}$. The slurry was then filtered with Whatman filter paper no.4 and stored in a blast freezer at $-80{ }^{\circ} \mathrm{C}$ before freeze-drying.

\section{Analyses}

\section{Yield of Gelatin}

The gelatin yield was calculated as the ratio of dried gelatin to the total weight of buffalo bone on a weight basis using the following formula as given in Eq. 1:

$$
\begin{aligned}
& \text { Yield }(\mathrm{g} / 100 \mathrm{~g}) \\
& =\frac{\text { Weight of freeze dried gelatin }(\mathrm{g})}{\text { Wet weight of buffalo bone }(\mathrm{g})} \times 100
\end{aligned}
$$

\section{Proximate composition}

The moisture, protein, and ash content of the buffalo bone gelatin were determined applying the method based on AOAC (2000) guidelines. Each measurement was carried out in triplicate.

\section{Colour measurement}

The colour properties of powdered buffalo bone gelatin were measured using colourimetry (Hunterlab Colorflex Ez, USA), which is based on the Hunter references expressed in lightness $\left(\mathrm{L}^{*}\right)$, redness $\left(\mathrm{a}^{*}\right)$, and yellowness $\left(\mathrm{b}^{*}\right)$.

\section{Uv-vis absorption}

The UV-vis absorption spectra of buffalo bone gelatin were recorded using a UV-vis spectrophotometer (Perkin Elmer, Lambda 25 , USA). Here, a sample $(1 \mathrm{mg} / \mathrm{mL})$ was dissolved in distilled water where the absorbance of the sample was recorded ranging between 190 and $400 \mathrm{~nm}$, and the resolution was set at $0.5 \mathrm{~nm}$, with distilled water as the standard. The reading for bovine gelatin standard was taken for comparison.

\section{Emulsifying capacity and stability}

Buffalo gelatin solution $(3 \%, 6 \mathrm{~mL}, \mathrm{w} / \mathrm{v})$ was homogenised with $(2 \mathrm{~mL})$ of soybean oil at $20,000 \mathrm{rpm}$ for $1 \mathrm{~min}$. The emulsion was then pipetted out at 0 and $10 \mathrm{~min}$ and diluted 100 -fold with $0.1 \%$ SDS. The solution was mixed thoroughly for $10 \mathrm{~s}$ using a vortex mixer before inserting into the cuvette to be analysed by the spectrophotometer to $500 \mathrm{~nm}$ absorbance. The emulsion activity index (EAI) and emulsion stability index (ESI) were calculated using Eqs. 2 and 3 as given below:

$$
\operatorname{EAI}\left(\mathrm{m}^{2} / \mathrm{g}\right)=\frac{2 \times 2.303 \times \mathrm{A} \times \mathrm{DF}}{1 \phi \mathrm{C} 10^{4}}
$$

Where $\mathrm{A}=\mathrm{A} 500, \mathrm{DF}=$ dilution factor $(100), \mathrm{l}=$ path length of cuvette $(\mathrm{m}), \Phi=$ oil volume fraction, and $\mathrm{C}=$ protein concentration in aqueous phase $(\mathrm{g} / \mathrm{ml})$.

$$
\operatorname{ESI}(\min )=\frac{\mathrm{A}_{0}}{\left(\mathrm{~A}_{0}-\mathrm{A}_{10}\right) \mathrm{x} \Delta \mathrm{t}}
$$

Where $\mathrm{A}_{0}=$ absorbance at $500 \mathrm{~nm}$ at the time point of $0 \mathrm{~min}$, $\mathrm{A}_{10}=$ absorbance at $500 \mathrm{~nm}$ at the time point of $10 \mathrm{~min}$, and $\Delta \mathrm{t}$ $=10 \mathrm{~min}$.

\section{Foaming activity and stability}

Foam expansion (FE) and foam stability (FS) of buffalo gelatin were determined, according to Xu et al. (2017). Gelatin solution $(3 \%, \mathrm{w} / \mathrm{v})$ was transferred into $100 \mathrm{~mL}$ cylinders and homogenised at 13,400 rpm for $1 \mathrm{~min}$ at room temperature. The sample was then allowed to stand for 0, 30, $60 \mathrm{~min}$ and FE and FS were determined according to Eqs. 4 and 5 below:

$$
\begin{aligned}
\mathrm{FE}(\%) & =\left(\mathrm{V}_{\mathrm{T}} / \mathrm{V}_{0}\right) / \mathrm{V}_{0} \times 100 \\
\mathrm{FS}(\%) & =\left(\mathrm{V}_{\mathrm{t}} / \mathrm{V}_{0}\right) / \mathrm{V}_{0} \times 100
\end{aligned}
$$

Where $\mathrm{V}_{\mathrm{T}}=$ total volume after whipping, $\mathrm{V}_{0}=$ original volume before whipping, and $V_{t}=$ total volume after leaving at room temperature for different times (30 and $60 \mathrm{~min}$ ).

\section{Statistical analysis}

All data obtained were analysed using the Statistical Package for the Social Sciences (SPSS) version 26.0 (IBM Corp., Armonk, NY).

\section{Results and Discussion}

\section{Yield of gelatin}

The yield of the extracted gelatin from buffalo bone with/without papain enzyme is presented in Table 1 . Nonenzymatic pre-treatment exhibited $7.50 \pm 0.08 \%$ while papainaided extraction (PE) was observed to increase the yield up to $29.92 \pm 0.52 \%$. Generally, the yield of gelatin depends substantially on the nature of raw material and the extraction 
methods employed (Jamilah et al., 2011). Also, depending on the initial content of collagen in the source material, a lower yield might be observed should the processing conditions be ineffective in releasing high crosslinking of the covalent bond within the collagen molecule to release gelatin.

The use of enzyme during the swelling process successfully increased the yield. This is also supported by previous gelatin production by Damrongsakkul et al. (2008) who extracted gelatin from rawhide with PE (60\% dry wt), Xu et al. (2017) for Yak skin with PE (26.34 $\pm 0.23 \%)$ and Ahmad et al. (2019) for bovine skin using PE $(24.56 \pm 0.23 \%)$ concluding that the extraction of gelatin using the enzyme enhances the yield of gelatin. However, the incorporation of the enzyme to be observed in order to enhance gelatin yield needs to be monitored, as this is a critical process to ensure good quality gelatin is obtained.

Table 1. Physico-chemical properties of buffalo bone gelatin

\begin{tabular}{lll}
\hline Properties & NE & PE \\
\hline Yield (\%)* & $7.50 \pm 0.08^{\mathrm{a}}$ & $29.92 \pm 0.52^{\mathrm{b}}$ \\
Moisture (\%)* & $3.09 \pm 0.71^{\mathrm{a}}$ & $2.50 \pm 0.22^{\mathrm{b}}$ \\
Protein (\%)* & $89.81 \pm 1.87^{\mathrm{a}}$ & $70.21 \pm 0.24^{\mathrm{b}}$ \\
Ash (\%)* & $6.39 \pm 0.78^{\mathrm{a}}$ & $8.45 \pm 0.43^{\mathrm{b}}$ \\
Colour & & \\
$\quad$ 'L' & $76.08 \pm 0.45^{\mathrm{a}}$ & $77.16 \pm 0.60^{\mathrm{a}}$ \\
'a' & $1.86 \pm 0.02^{\mathrm{a}}$ & $1.69 \pm 0.02^{\mathrm{b}}$ \\
'b' & $6.76 \pm 0.14^{\mathrm{a}}$ & $7.68 \pm 0.25^{\mathrm{b}}$ \\
$\quad \begin{array}{l}\text { Absorbance } \\
\text { (nm) }\end{array}$ & 210 & 210
\end{tabular}

*Values signify means \pm standard deviation of triplicates. Different superscript letters indicate significant differences $(\mathrm{p}<$ 0.05 ) within the same row.

\section{Moisture content}

The moisture content for powdered PE and NE was $(2.50 \pm$ $0.22 \%)$ and $(3.09 \pm 0.71 \%)$ respectively, as shown in Table 1 . Accordingly, this shows that the drying method by freeze-drying was highly effective for both gelatin. The slight difference in the moisture content between the samples was due to two different types of pre-treatment. The values obtained were in agreement with the GMIA standard (2019), which states that the moisture content of commercial gelatin should not exceed $12 \%$. The moisture content for $\mathrm{PE}$ and $\mathrm{NE}$ was much lower when compared to chicken feet gelatin $(6.34 \%)$ by Rahman and Jamalulail (2012) and cow bone (7.87 \%) reported by Arioui et al. (2018). The moisture content percentage is strongly influenced by the drying time, temperature, humidity level during storage, and the type of packaging used (Rahman and Jamalulail, 2012).

\section{Protein Content}

The protein content of gelatin derived from buffalo bone is presented in Table 1. Here, the protein content of PE and NE are shown to be relatively high, with NE being significantly higher $(p<0.05)$ compared to PE. The lower protein content observed in PE was possibly due to over hydrolysis of the protein by enzymatic pre-treatment. Ahmad etal. (2019) stated that papain pre-treatment at a certain concentration and contact time caused severe cleavage of collagen chains which led to the formation of shorter chains. In contrast, Haryanti et al. (2019) reported that the increased concentration of enzyme and contact time resulted in lower protein content for gelatin derived from rabbitfish skin. Nonetheless, the protein content in NE for this study was found to be higher than those reported for Yellowfin sole fish gelatin (84.67 \%) by Mi et al. (2019), Tigertoothed croaker fish $(82.05 \%)$ and Pink perch (69.49\%) by Koli et al. (2012).

\section{Ash content}

The ash content of PE and NE was found to be significantly higher $(\mathrm{p}<0.05)$ than that of NE (refer to Table 1). The NE process in this study was found to remove ash more efficiently compared to the enzymatic process. This may be due to the presence of trace elements in the buffer solution used in the enzymatic treatment. However, the ash value obtained for the buffalo bone gelatin was lower than reported for pekin duck feet gelatin (9.54 $\pm 1.44 \%$ ) (Abedinia et al., 2017) and bovine bone gelatin (13.33 $\pm 0.57 \%$ ) (Arioui et al., 2018). Therefore, this indicates that the demineralising process during pre-treatment utilised in this study effectively reduced the minerals in the sample.

\section{Colour}

The colour measurement results for NE and PE are shown in Table 1. Here, the 'L' (lightness) value for both $\mathrm{NE}$ and PE showed no significant difference $(p<0.05)$. However, there were significant differences $(p<0.05)$ in ' $a$ ' (redness) and ' $b$ ' (yellowness) between the NE and PE gelatin. According to GMIA (2019), the gelatin colour is impacted by raw materials but does not influence the nature and chemical quality of gelatin. The results obtained agree with the work by GMIA (2019), where the standard for the colour of gelatin ranged from colourless to yellow. This could be observed by the high ' $L$ ' value in the gelatin samples as portrayed by the higher ' $b$ ' value than ' $a$ ' which indicates the colour properties were closer to yellowness. Accordingly, the results suggest that buffalo gelatin colour properties are similar to the industrial standard, therefore allowing it to be applied in various types of products since no significant colour alteration will be observed.

\section{UV-Vis Absorption}

The UV-vis absorption spectra of PE and NE gelatin is depicted in Table 1. The results show that the absorption peak of NE and PE gelatin was at $210 \mathrm{~nm}$. Commercial bovine gelatin was also reported for comparison, in which the absorption peak was recorded at $220 \mathrm{~nm}$. Moreover, the UV-vis peak absorption of $\mathrm{PE}$ and NE are paralleled with the spectrum characters of bovine and porcine gelatin in Hermanto et al. (2013). Likewise, a similar absorption peak range was reported in gelatin from the source of various aquatic species such as red snapper $(209 \mathrm{~nm})$ by Jeya Shakila et al. (2012) and Yellowfin sole ( $211 \mathrm{~nm}$ ) by Mi et al. (2019). As such, the absorption reading of NE and PE at a wavelength between $270 \mathrm{~nm}$ and $280 \mathrm{~nm}$ (data is not shown) indicates the presence of amino acid residues aside from the main amino acids in gelatin, the amino acid (Phe), tyrosine (Tyr) and tryptophan (Trp) (Mi et al., 2019). In general, usual UV-vis absorption of gelatin in the range between $190 \mathrm{~nm}$ and $240 \mathrm{~nm}$ confirms the presence of peptide bonds $(C=0)$ existing in the gelatin polypeptide chain (Xu et al., 2017).

\section{Emulsifying property and capacity}

The EAI and ESI of the PE and NE gelatin are presented in Table 2. Here, the EAI obtained for PE and NE was $(11.19 \pm 0.29$ $\left.\mathrm{m}^{2} / \mathrm{g}\right)$ and $\left(12.03 \pm 0.54 \mathrm{~m}^{2} / \mathrm{g}\right)$, respectively. There was no significant difference observed for both samples $(p>0.05)$. The EAI value or NE was similar to gelatin extracted by Mulyani et al. (2019) $\left(12.03 \mathrm{~m}^{2} / \mathrm{g}\right)$. In contrast, PE was slightly lower as compared to Mulyani et al. (2019) for gelatin extracted from buffalo skin. Meanwhile, for the ESI value, PE (30.05 $\pm 0.38 \mathrm{~min})$ was significantly higher than that of NE $(3.76 \pm 0.74 \mathrm{~min})$. Moreover, the ESI value of PE and NE was much lower than gelatin extracted from cow bone using crude acid protease cow 
Table 2. Functional properties of buffalo bone gelatin

\begin{tabular}{lll}
\hline Properties & NE & PE \\
\hline Emulsifying Activity Index/EAI $\left(\mathrm{m}^{2} / \mathrm{g}\right)$ & $12.03 \pm 0.54^{\mathrm{a}}$ & $11.19 \pm 0.29^{\mathrm{a}}$ \\
Emulsion Stability Index/ESI (min) & $3.76 \pm 0.74^{\mathrm{a}}$ & $30.05 \pm 0.38^{\mathrm{b}}$ \\
Foam Expansion/FE (\%) & $18.87 \pm 1.21^{\mathrm{a}}$ & $20.33 \pm 0.58^{\mathrm{a}}$ \\
Foam Stability/FS $(\%)$ & & \\
$\quad 30 \mathrm{~min}$ & $13.33 \pm 1.15^{\mathrm{a}}$ & $13.00 \pm 1.00^{\mathrm{a}}$ \\
$\quad 60 \mathrm{~min}$ & $12.67 \pm 1.53^{\mathrm{a}}$ & $11.33 \pm 0.58^{\mathrm{a}}$ \\
\hline
\end{tabular}

*Values signify means \pm standard deviation of triplicates. Different superscript letters indicate significant differences (p $<0.05)$ within the same row.

abomasum (CAPC) (50.52 min) as reported by Mulyani et al. (2019). Here, the EAI was mainly influenced by the variations in intrinsic properties, protein conformation, in addition to the composition of amino acids (Zilhadia et al., 2018). Moreover, the ESI was impacted by the high molecular weight of peptide and the concentration of hydrophobic peptides (Duan et al., 2018).

\section{Foaming capacity and stability}

As shown in Table 2, the foam expansion (FE) of NE was $18.87 \pm 1.21 \%$, and PE was $20.33 \pm 0.58 \%$ with no significant difference $(\mathrm{p}>0.05)$. Whereas the foam stability for NE was $(13.33 \pm 1.15 \%)$ and $P E(13.00 \pm 1.00 \%)$ at $30 \mathrm{~min}$, while at 60 min, PE $(12.67 \pm 1.53 \%)$ and NE $(11.33 \pm 0.58 \%)$ showing no significant difference ( $p>0.05)$. Mulyani et al. (2019) reported a higher FE (102.93 \%) and FS (44.91-55.00 \%) value compared to the result of this study. The study by Khiari et al. (2013), of enzymatically extracted fish gelatin, resulted in more stable foam as compared to NE due to high negatively charged amino acids in the gelatin. Accordingly, this prevents the charge neutralisation in gelatin prompting high stability of the foam. As such, protein concentration plays an important role in creating a more stable and dense foam mainly due to interconnected space film (interfacial) paralleled with the increment of protein concentration (Mi et al., 2019).

\section{Conclusion}

Gelatin from buffalo bone was successfully extracted using non-enzymatic and enzymatic pre-treatment. Papain extraction resulted in significantly higher yield compared to nonenzymatic extraction (NE). As such, the gelatin obtained were of acceptable properties, even though some differences were observed in both treatments. In future research, the incorporation of enzymatic pre-treatment in gelatin extraction could be further explored with a specific focus on the improvement of process efficiency without compromising the quality of gelatin.

\section{Acknowledgement}

The author would like to acknowledge the Ministry of Education, Malaysia and Universiti Malaysia Sabah for the financial supported provided under the Fundamental Research Grant Scheme (FRGS-0482-2018).

\section{Author contributions}

Muhammad Yazid Samatra: Performed the research works and drafted the manuscript. Afifah Azmi: Performed the research works. Sharifudin Md Shaarani: Supervision and Project administration. Umi Hartina Mohamad Razali: Supervision, Reviewing and Editing the final manuscript.

\section{Conflict of interests}

The authors have declared no conflict of interest.

\section{References}

Abedinia, A., Ariffin, F., Huda, N., \& Mohammadi, A. (2017). Extraction and characterization of gelatin from the feet of Pekin duck (Anas platyrhynchos domestica) as affected by acid, alkaline, and enzyme pretreatment. International Journal of Biological Macromolecules, 98, 586-594 https://doi.org/10.1016/j.ijbiomac.2017.01.139

Ahmad, T., Ismail, A., Ahmad, S. A., Khalil, K. A., Kee, L. T., Awad, E. A., \& Sazili, A. Q. (2019). Physicochemical characteristics and molecular structures of gelatin extracted from bovine skin: effects of actinidin and papain enzymes pretreatment. International Journal of Food Properties, 22(1), 138-153. https://doi.org/10.1080/10942912.2019.1576731

AOAC. (2000). Official methods of analysis. Arlington: Association of Official Analytical Chemists Inc

Arioui, F., Saada, D. A., \& Cheriguene, A. (2018). Functional properties of bovine bone gelatin and impact on physicochemical, microbiological and organoleptic quality of set yogurt. Biotechnology, 17(1), 1-11. https://doi.org/10.3923/biotech.2018.1.11

Damrongsakkul, S., Ratanathammapan, K., Komolpis, K., \& Tanthapanichakoon, W. (2008). Enzymatic hydrolysis of rawhide using papain and neutrase. Journal of Industrial and Engineering Chemistry, 14(2), 202-206. https://doi.org/10.1016/j.jiec.2007.09.010

Duan, R., Zhang, J., Liu, L., Cui, W., \& Regenstein, J. M. (2018). The functional properties and application of gelatin derived from the skin of channel catfish (Ictalurus punctatus). Food Chemistry, 239, 464-469. https://doi.org/10.1016/j.foodchem.2017.06.145

GMIA. (2019). GMIA, Gelatin Handbook. In Gelatin Manufacturers Institute Of America. Retrieved on 10 September 2019 from Website: https://www.gelatingmia.com

Haryati, D., Nadhifa, L., Humairah, \& Abdullah, N. (2019). Extraction and Characterization of Gelatin from Rabbitfish Skin (Siganus canaliculatus) with Enzymatic Method Using Bromelin Enzyme. IOP Conference Series: Earth and Environmental Science, 355(1). https://doi.org/10.1088/17551315/355/1/012095

Hermanto, S., Sumarlin, L. O., \& Fatimah, W. (2013). Differentiation of Bovine and Porcine Gelatin Based on Spectroscopic and Electrophoretic Analysis. Journal of Food and Pharmaceutical Sciences, May, 68-73.

Hosseini-Parvar, S. H., Keramat, J., Kadivar, M., Khanipour, E., \& Motamedzadegan, A. (2009). Optimising conditions for enzymatic extraction of edible gelatin from the cattle bones using response surface methodology. International Journal of Food Science and Technology, $44(3), \quad 467-475 . \quad$ https://doi.org/10.1111/j.13652621.2008.01745.x

Jamilah, B., Tan, K. W., Hartina, M. R. U., \& Azizah, A. (2011). Food Hydrocolloids Gelatins from three cultured freshwater 
fish skins obtained by liming process. Food Hydrocolloids, 25(5), 1256-1260. https://doi.org/10.1016/j.foodhyd.2010.11.023

Jeya Shakila, R., Jeevithan, E., Varatharajakumar, A., Jeyasekaran, G., \& Sukumar, D. (2012). Functional characterization of gelatin extracted from bones of red snapper and grouper in comparison with mammalian gelatin. LWT - Food Science and Technology, 48(1), 30-36. https://doi.org/10.1016/j.lwt.2012.03.007

Khiari, Z., Rico, D., Martin-Diana, A. B., \& Barry-Ryan, C. (2013). Comparison between gelatines extracted from mackerel and blue whiting bones after different pretreatments. Food Chemistry, 139(1-4), 347-354. https://doi.org/10.1016/j.foodchem.2013.01.017

Koli, J. M., Basu, S., Nayak, B. B., Patange, S. B., Pagarkar, A. U., \& Gudipati, V. (2012). Functional characteristics of gelatin extracted from skin and bone of Tiger-toothed croaker (Otolithes ruber) and Pink perch (Nemipterus japonicus). Food and Bioproducts Processing, 90(3), 555-562. https://doi.org/10.1016/j.fbp.2011.08.001

Li, F., Jia, D., \& Yao, K. (2009). Amino acid composition and functional properties of collagen polypeptide from Yak (Bos grunniens) bone. LWT - Food Science and Technology, 42(5), 945-949. https://doi.org/10.1016/j.lwt.2008.12.005

Li, Y., Chen, F., Zou, J., Zhi, M., \& Huang, G. (2018). Gelatin extraction of Alaska Pollock (Theragra chalcogramma) dry skin. American Journal of Biochemistry and Biotechnology, 14(1), 13-19. https://doi.org/10.3844/ajbbsp.2018.13.19

Ma, Y., Zeng, X., Ma, X., Yang, R., \& Zhao, W. (2019). A simple and eco-friendly method of gelatin production from bone: One-step biocatalysis. Journal of Cleaner Production, 209, 916-926. https://doi.org/10.1016/j.jclepro.2018.10.313

Mi, H., Wang, C., Chen, J., Xu, Y., Li, X., Li, J., Sun, X., Mao, L., Ma, Y., \& Lao, M. (2019). Characteristic and Functional
Properties of Gelatin from the Bones of Alaska Pollock (Theragra chalcogramma) and Yellowfin Sole (Limanda aspera) with Papain-Aided Process. Journal of Aquatic Food Product Technology, 28(3), 287-297. https://doi.org/10.1080/10498850.2019.1577933

Mulyani, S., Pranoto, Y., Setyabudi, F. M. C. S., Legowo, A. M., \& Santoso, U. (2019). The Functional Properties of Buffalo skin Gelatin Extracted Using Crude Acid Protease from Cow's Abomasum. Journal of Applied Food Technology, 6(2), 3-6. https://doi.org/10.17728/jaft.6464

Rahman, M., \& Jamalulail, S. A. (2012). Extractions, Physicochemical Characterizations And Sensory Quality Of Chicken Feet Gelatin. Borneo Science, March, 1-13.

Research, \& Market. (2019). 2019 Future of Global Gelatin Market to 2025 - Growth Opportunities, Competition, Trends and Outlook of Gelatin Across Applications and Regions Report.

Xu, M., Wei, L., Xiao, Y., Bi, H., Yang, H., \& Du, Y. (2017). Physicochemical and functional properties of gelatin extracted from Yak skin. International Journal of Biological Macromolecules, 95, 1246-1253. https://doi.org/10.1016/j.ijbiomac.2016.11.020

Zhao, H., Wang, S. Q., Qing, L. L., Liu, L. L., \& Zhang, Y. P. (2016). Expression of BSE-associated proteins in the CNS and lymphoreticular tissues of cattle and buffalo. Science Bulletin, 61(17), 1377-1383. https://doi.org/10.1007/s11434-016-1130-y

Zilhadia, Yahdiana, H., Irwandi, J., \& Effionora, A. (2018). Characterization and functional properties of gelatin extracted from goatskin. International Food Research Journal, 25(1), 275-281. 